\title{
Deteksi Plagiarisme Abstrak Skripsi dengan Menggunakan Algoritma Rabin Karp (Studi Kasus: Fakultas Ilmu Komputer Universitas Singaperbangsa Karawang)
}

\author{
Indra Gunawan \\ Universitas Singaperbangsa Karawang \\ Karawang, Indonesia \\ indra.16114@student.unsika.ac.id
}

\author{
Ultach Enri \\ Universitas Singaperbangsa Karawang \\ Karawang, Indonesia \\ ultach.enri@staff.unsika.ac.id
}

\author{
Yuyun Umaidah \\ Universitas Singaperbangsa Karawang \\ Karawang, Indonesia \\ yuyun.umaidah@staff.unska.ac.id
}

\begin{abstract}
Pada lingkup pendidikan khususnya perguruan tinggi plagiarisme sering terlihat. Umumnya plagiarisme terjadi karena rasa malas dan ingin cepat dalam menyelesaikan urusan tugasnya. Algoritma Rabin Karp merupakan algoritma pencarian string, algoritma ini digunakan untuk mendeteksi plagiarisme pada teks. Tujuan penelitian mengetahui hasil evaluasi yang didapat dari proses Algoritma Rabin Karp. Data penelitian akan melewati semua tahapan preprocessing (case folding, tokenizing, filtering, dan stemming) dan melewati sebagian tahapan preprocessing (case folding), k-gram yang diuji yaitu 2gram, 3gram, 4gram, 5gram, dan 6gram kemudian melewati tahapan hashing dan mendapatkan nilai fingerprint kemudian diuji tingkat kemiripannya menggunakan Dice Similarity Coeffcient. Metode penelitian yang digunakan yaitu metode Text Mining yang memiliki tahapan Akuisisi, Text Preprocessing, Modeling, dan Evaluasi. Dari data yang digunakan menghasilkan nilai rata-rata total kemiripan $86.84 \%$ pada $2 \mathrm{gram}, 69.56 \%$ pada $3 \mathrm{gram}, 56.06 \%$ pada 4gram, $48.71 \%$ pada 5gram, dan $\mathbf{4 4 . 3 0 \%}$ pada 6gram. hasil dari tahapan Preprocessing dengan hasil dari tahapan Sebagian Preprocessing, memiliki perbedaan yaitu, hasil tahapan Preprocessing lebih kecil persentase kemiripannya daripada hasil sebagian Preprocessing, ini disebabkan penghilangan kata pada tahapan filtering dan perubahan kata pada tahapan stemming. Dapat disimpulkan bahwa dari data yang digunakan terlihat adanya tindakan plagiarisme pada abstrak, hal ini didukung dengan adanya data yang memiliki nilai kemiripan hingga $100 \%$.
\end{abstract}

Kata kunci_- Plagiarisme, Rabin Karp, Text Mining

\section{Pendahuluan}

Pada lingkup pendidikan khususnya pada perguruan tinggi plagiarisme masih sering kita lihat. Umumnya pelaku plagiarisme adalah mahasiswa, plagiarisme ini dilakukan saat pengerjaan tugas yang diberikan oleh dosen dan kemudian mahasiswa melakukan teknik copy \& paste baik itu berasal dari internet dimana semua orang dapat mengakses maupun hasil karya orang lain atau hasil plagiarisme dari temannya, karena hal tersebut dapat memicu tindakan plagiarisme pada penulisan skripsi mahasiswa nantinya. Plagiarisme atau biasa disebut plagiat adalah pencurian hasil karya orang lain dan menjadikannya milik sendiri [1]. Adapun klasifikasi berdasarkan proporsi atau persentase kata/kalimat/paragraf yang dibajak yaitu : (1) Plagiarisme ringan dimana kata yang dibajak < $30 \%$, (2) plagiarisme sedang dimana kata yang dibajak berkisar dari 30\% hingga 70\%, dan (3) plagiarisme berat dimana kata yang dibajak yaitu melebihi dari $70 \%$ [2].

Penelitian yang dilakukan oleh Sibarani, Magdalena, dan Dharma yaitu Analisa Perbandingan Sistem Pendeteksian Kemiripan Judul Skripsi Menggunakan Algoritma Winnowing Dan Algoritma Rabin Karp menyimpulkan bahwa berdasarkan pengujian sistem, tingkat akurasi untuk kemiripan judul dan beserta isinya dengan Algoritma winnowing dan Algoritma Rabin karp mendekati 75\%, dan menghasilkan persentase plagiarisme sebesar 97,22\% [3]. Algoritma Rabin Karp merupakan algoritma pencarian string yang menggunakan fungsi hashing untuk membandingkan string yang dicari (m) dengan substring pada teks (n) [4].

Identifikasi Bentuk Tindak Plagiat Pada Penulisan Skripsi Mahasiswa Program Studi Pendidikan Fisika Unsyiah menyimpulkan bahwa penelitian tersebut meneliti dengan menggunakan 134 skripsi mahasiswa Program Studi Pendidikan Fisika tahun 2016, dan menggunakan bantuan software http:/www.smallseotools.com/ menyimpulkan bahwa dari 134 skripsi yang diteliti pada landasan teoritis teridentifikasi plagiat penuh sebesar $80,55 \%$ [5].

Langkah untuk mendeteksi plagiarisme yaitu menggunakan konsep kemiripan dokumen dengan menggunakan Text Mining. Text Mining itu sendiri adalah ilmu untuk mencari dan mengukur data yang berupa teks yang bertujuan untuk mencari kata-kata yang dapat merepresentasikan isi dan maksud dari teks tersebut kemudian melakukan penganalisaan lebih lanjut [1]. Penelitian ini menggunakan algoritma Rabin Karp dalam mendeteksi plagiarisme pada teks karena lebih efektif dan praktis dibandingkan dengan algoritma yang lain, algoritma ini melakukan prinsip perhitungan dengan menghitung nilai hash untuk mendapatkan hasil gram-nya kemudian proses ini akan dilakukan secara berkelanjutan [3]. K-gram merupakan rangkaian terms yang panjang dengan nilai panjang k. Metode K-gram ini mengambil setiap karakter huruf dengan jumlah nilai k dari sebuah teks secara terus menerus kesebelah kanan teks dari awal teks hingga akhir teks. K-gram akan memecah string ke dalam potongan substring sebanyak k [6]. Algoritma Rabin Karp ini adalah algoritma yang dapat mencari kata dengan banyak pola sekaligus [7]. 


\section{Metodologi}

Metodologi yang digunakan pada penelitian ini yaitu menggunakan metode Text Mining. Proses pada metode Text Mining melawati empat tahapan yaitu akuisisi, text preprocessing, modeling, dan evaluasi.

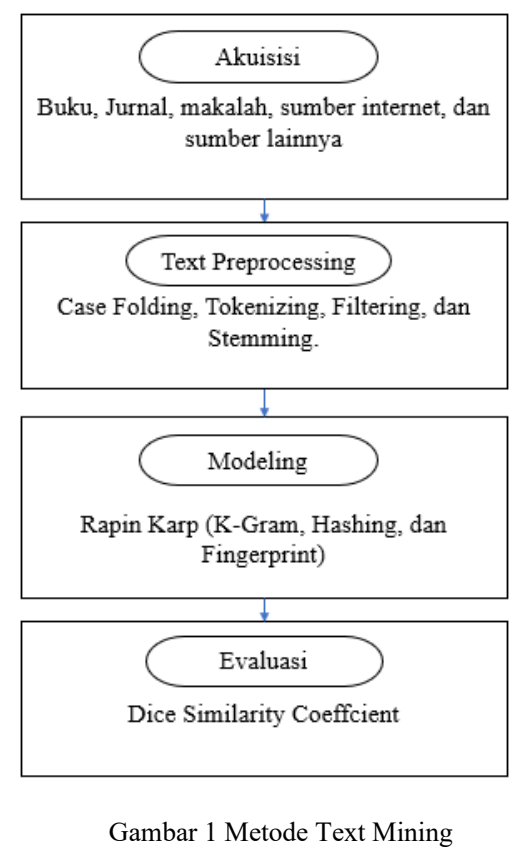

Gambar 1 memiliki tahapan yaitu peneliti akan melakukan akuisisi yang didalamnya akan melakukan pencarian referensi, kemudian akan melakukan text preprocessing atau mentransformasikan kata. Kemudian akan malakukan Modeling atau pengimplementasian algoritma Rabin Karp tahapannya yaitu k-gram atau pengambilan setiap karakter huruf dengan jumlah nilai $\mathrm{k}$ dari sebuah teks secara terus menerus kesebelah kanan teks dari awal teks hingga akhir teks, Hashing merupakan cara untuk mengubah karakter string menjadi integer yang disebut nilai hash, Fingerprint merupakan bagian dari nilai hash dari proses hashing yang memiliki nilai yang sama, dan terakhir akan mendapatkan suatu kesimpulan menggunakan Dice Similarity Coeffcient. Dice Similarity Coeffcient adalah metode untuk menghitung kemiripan fingerprint dengan cara pendekatan K-Gram yang digunakan pada kedua teks yang diuji [8].

\section{HASIL DAN PEMBAHASAN}

Data abstrak skripsi yang diperoleh dari tahun 2018-2019, Data abstrak yang diperoleh yaitu sekitar 470 data abstrak skripsi. berikut ini merupakan data abstrak yang digunakan yaitu.

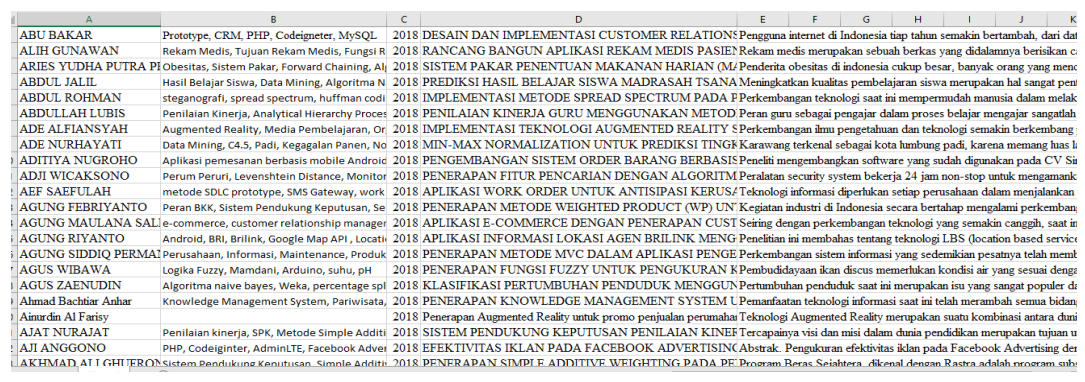

Gambar 2 Data Skripsi Fakultas Ilmu Komputer

Data yang digunakan akan diambil kata kunci yang telah diubah menjadi kode yaitu ak (Android-Kripnografi), mw (MysqlWaterfall), mv (Mysql-Visual Studio), dn (Data Mining-Naïve Bayes), ws (Waterfall-Sistem Pendukung Keputusan), wsa (WaterfallSimple Additive Weighting), ss (System Pendukung Keputusan-Simple Additive Weighting), cmp (Customer Relationship Management-Mysql-Php), cp (Codeigniter-Php), cm (Codeigniter-Mysql), es (Expert System Development Life Cycle-Sistem Pakar), am (Augmented Reality-Media Pembelajaran), dp (Data Mining-Padi), de (Data Mining-C45), mw (Manajemen BandwithWireless), wp (Web-Php), wm (Web-Mysql), cw (Codeigniter-Waterfall), dan kn (Klasifikasi-Naïve Bayes).

\section{A. Text Preprocessing}

Tahap Text Preprocessing ini memiliki beberapa tahapan yang dilakukan seperti case folding, tokenizing, filtering, dan stemming. Hasil dari tahapan ini yaitu sebagai berikut. 


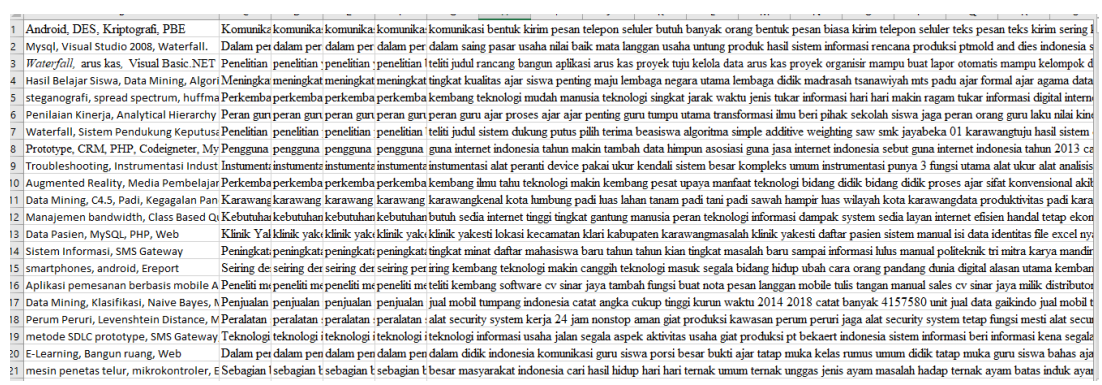

Gambar 3 Hasil Preprocessing

Gambar 3 merupakan gambar hasil dari tahapan Case Folding mengubah huruf menjadi huruf kecil atau tanpa huruf kapital dan menghilangkan karakter seperti tanda baca, tahapan Tokenizing pemotongan string berdasarkan tiap kata yang menyusunnya, tahapan Filtering mengambil kata-kata yang penting dari hasil proses Tokenizing, dan tahapan Stemming yaitu proses pengembalian kata dari berbagai bentukan menjadi kata dasar.

\section{B. Rabin Karp}

Rabin Karp memiliki beberapa tahapan yang dilakukan seperti K-gram, Hashing, Fingerprint, dan Dice Similarity Coeffcient. Hasil dari algoritma ini yaitu sebagai berikut.

Tabel 1 Customer Relationship Management-Mysql-Php

\begin{tabular}{|l|c|c|c|c|c|}
\hline \multicolumn{1}{|c|}{ Kode } & $\mathbf{2}$ gram & $\mathbf{3}$ gram & $\mathbf{4}$ gram & $\mathbf{5}$ gram & $\mathbf{6}$ gram \\
\hline cmp1-cmp2 & $81.00 \%$ & $49.35 \%$ & $29.59 \%$ & $21.53 \%$ & $17.05 \%$ \\
\hline cmp1-cmp3 & $81.99 \%$ & $49.94 \%$ & $30.21 \%$ & $21.87 \%$ & $17.20 \%$ \\
\hline cmp1-cmp4 & $81.99 \%$ & $49.94 \%$ & $30.21 \%$ & $21.87 \%$ & $17.20 \%$ \\
\hline cmp1-cmp5 & $91.02 \%$ & $82.58 \%$ & $78.51 \%$ & $77.09 \%$ & $75.93 \%$ \\
\hline cmp1-cmp6 & $93.47 \%$ & $86.23 \%$ & $83.82 \%$ & $81.49 \%$ & $81.05 \%$ \\
\hline cmp2-cmp3 & $99.10 \%$ & $98.23 \%$ & $97.72 \%$ & $97.10 \%$ & $96.84 \%$ \\
\hline cmp2-cmp4 & $99.10 \%$ & $98.23 \%$ & $97.72 \%$ & $97.10 \%$ & $96.84 \%$ \\
\hline cmp2-cmp5 & $90.43 \%$ & $68.03 \%$ & $52.63 \%$ & $47.09 \%$ & $44.21 \%$ \\
\hline cmp2-cmp6 & $76.16 \%$ & $46.40 \%$ & $27.69 \%$ & $19.56 \%$ & $15.42 \%$ \\
\hline cmp3-cmp4 & $100 \%$ & $100 \%$ & $100 \%$ & $100 \%$ & $100 \%$ \\
\hline cmp3-cmp5 & $91.33 \%$ & $68.36 \%$ & $52.87 \%$ & $46.88 \%$ & $43.68 \%$ \\
\hline cmp3-cmp6 & $77.23 \%$ & $47.06 \%$ & $28.41 \%$ & $19.96 \%$ & $15.60 \%$ \\
\hline cmp4-cmp5 & $91.33 \%$ & $68.36 \%$ & $52.87 \%$ & $46.88 \%$ & $43.68 \%$ \\
\hline cmp4-cmp6 & $77.23 \%$ & $47.06 \%$ & $28.41 \%$ & $19.96 \%$ & $15.60 \%$ \\
\hline cmp5-cmp6 & $84.44 \%$ & $68.48 \%$ & $61.74 \%$ & $57.91 \%$ & $56.39 \%$ \\
\hline cmp11-cmp12 & $84.81 \%$ & $57.80 \%$ & $37.56 \%$ & $27.68 \%$ & $21.39 \%$ \\
\hline cmp11-cmp13 & $85.14 \%$ & $58.45 \%$ & $38.06 \%$ & $27.98 \%$ & $21.58 \%$ \\
\hline cmp11-cmp14 & $85.14 \%$ & $58.45 \%$ & $38.06 \%$ & $27.98 \%$ & $21.58 \%$ \\
\hline cmp11-cmp15 & $92.22 \%$ & $86.85 \%$ & $81.97 \%$ & $79.32 \%$ & $77.13 \%$ \\
\hline cmp11-cmp16 & $96.34 \%$ & $92.14 \%$ & $88.29 \%$ & $86.31 \%$ & $85.47 \%$ \\
\hline cmp12-cmp13 & $99.16 \%$ & $98.41 \%$ & $98.43 \%$ & $98.19 \%$ & $98.03 \%$ \\
\hline cmp12-cmp14 & $99.16 \%$ & $98.41 \%$ & $98.43 \%$ & $98.19 \%$ & $98.03 \%$ \\
\hline cmp12-cmp15 & $92.68 \%$ & $71.12 \%$ & $55.61 \%$ & $47.89 \%$ & $43.13 \%$ \\
\hline cmp12-cmp16 & $81.31 \%$ & $56.28 \%$ & $35.97 \%$ & $27.04 \%$ & $21.24 \%$ \\
\hline cmp13-cmp14 & $100 \%$ & $100 \%$ & $100 \%$ & $100 \%$ & $100 \%$ \\
\hline cmp13-cmp15 & $92.97 \%$ & $71.76 \%$ & $56.10 \%$ & $47.95 \%$ & $42.90 \%$ \\
\hline
\end{tabular}




\begin{tabular}{|c|c|c|c|c|c|}
\hline Kode & 2 gram & 3 gram & 4 gram & 5 gram & 6 gram \\
\hline cmp13-cmp16 & $81.66 \%$ & $56.99 \%$ & $36.54 \%$ & $27.26 \%$ & $21.47 \%$ \\
\hline cmp14-cmp15 & $92.97 \%$ & $71.76 \%$ & $56.10 \%$ & $47.95 \%$ & $42.90 \%$ \\
\hline cmp14-cmp16 & $81.66 \%$ & $56.99 \%$ & $36.54 \%$ & $27.26 \%$ & $21.47 \%$ \\
\hline cmp15-cmp16 & $88.51 \%$ & $78.53 \%$ & $69.27 \%$ & $64.25 \%$ & $60.80 \%$ \\
\hline
\end{tabular}

Tabel 2 Data Mining-C45

\begin{tabular}{|c|c|c|c|c|c|}
\hline Kode & 2 gram & 3 gram & 4 gram & 5 gram & 6 gram \\
\hline $\mathrm{dc} 1-\mathrm{dc} 2$ & $71.72 \%$ & $40.99 \%$ & $25.39 \%$ & $18.35 \%$ & $14.72 \%$ \\
\hline $\mathrm{dc} 1-\mathrm{dc} 3$ & $74.30 \%$ & $41.83 \%$ & $22.75 \%$ & $15.15 \%$ & $11.31 \%$ \\
\hline $\mathrm{dc} 1-\mathrm{dc} 4$ & $78.43 \%$ & $53.77 \%$ & $39.57 \%$ & $32.90 \%$ & $28.81 \%$ \\
\hline $\mathrm{dc} 1-\mathrm{dc} 5$ & $75.14 \%$ & $43.66 \%$ & $23.31 \%$ & $16.55 \%$ & $12.45 \%$ \\
\hline dc1-dc6 & $81.44 \%$ & $65.27 \%$ & $53.04 \%$ & $47.12 \%$ & $42.16 \%$ \\
\hline $\mathrm{dc} 2-\mathrm{dc} 3$ & $81.74 \%$ & $57.18 \%$ & $44.15 \%$ & $37.54 \%$ & $33.02 \%$ \\
\hline $\mathrm{dc} 2-\mathrm{dc} 4$ & $73.77 \%$ & $42.12 \%$ & $28.76 \%$ & $21.45 \%$ & $16.87 \%$ \\
\hline $\mathrm{dc} 2-\mathrm{dc} 5$ & $78.79 \%$ & $55.56 \%$ & $40.84 \%$ & $34.11 \%$ & $29.58 \%$ \\
\hline $\mathrm{dc} 2-\mathrm{dc} 6$ & $70.55 \%$ & $40.21 \%$ & $24.02 \%$ & $17.42 \%$ & $13.32 \%$ \\
\hline $\mathrm{dc} 3-\mathrm{dc} 4$ & $77.17 \%$ & $44.65 \%$ & $27.99 \%$ & $19.65 \%$ & $14.28 \%$ \\
\hline dc3-dc5 & $77.25 \%$ & $54.57 \%$ & $35.78 \%$ & $26.57 \%$ & $21.88 \%$ \\
\hline dc3-dc6 & $70.95 \%$ & $40.39 \%$ & $23.21 \%$ & $15.50 \%$ & $11.33 \%$ \\
\hline $\mathrm{dc} 4-\mathrm{dc} 5$ & $79.58 \%$ & $47.34 \%$ & $28.60 \%$ & $20.57 \%$ & $15.71 \%$ \\
\hline dc4-dc6 & $76.75 \%$ & $52.22 \%$ & $37.45 \%$ & $30.30 \%$ & $26.33 \%$ \\
\hline dc5-dc6 & $74.01 \%$ & $40.99 \%$ & $20.71 \%$ & $12.76 \%$ & $8.25 \%$ \\
\hline $\mathrm{dc} 11-\mathrm{dc} 12$ & $74.29 \%$ & $48.36 \%$ & $30.79 \%$ & $22.63 \%$ & $18.09 \%$ \\
\hline de $11-d c 13$ & $78.00 \%$ & $51.75 \%$ & $32.47 \%$ & $23.62 \%$ & $18.11 \%$ \\
\hline dc11-dc14 & $81.31 \%$ & $59.85 \%$ & $45.35 \%$ & $36.01 \%$ & $30.70 \%$ \\
\hline $\mathrm{dc} 11-\mathrm{dc} 15$ & $78.88 \%$ & $50.58 \%$ & $29.58 \%$ & $21.09 \%$ & $15.44 \%$ \\
\hline dc11-dc16 & $84.32 \%$ & $70.00 \%$ & $58.26 \%$ & $51.41 \%$ & $45.98 \%$ \\
\hline $\mathrm{dc} 12-\mathrm{dc} 13$ & $81.84 \%$ & $61.52 \%$ & $45.41 \%$ & $38.15 \%$ & $33.13 \%$ \\
\hline dc12-dc14 & $76.77 \%$ & $51.73 \%$ & $36.55 \%$ & $27.19 \%$ & $20.77 \%$ \\
\hline $\mathrm{dc} 12-\mathrm{dc} 15$ & $80.30 \%$ & $59.96 \%$ & $45.16 \%$ & $37.19 \%$ & $32.18 \%$ \\
\hline $\mathrm{dc} 12-\mathrm{dc} 16$ & $75.20 \%$ & $50.61 \%$ & $32.83 \%$ & $23.41 \%$ & $18.06 \%$ \\
\hline dc13-dc14 & $79.25 \%$ & $54.50 \%$ & $37.29 \%$ & $26.07 \%$ & $19.46 \%$ \\
\hline dc13-dc15 & $81.24 \%$ & $62.11 \%$ & $43.38 \%$ & $32.80 \%$ & $27.07 \%$ \\
\hline dc13-dc16 & $75.38 \%$ & $51.36 \%$ & $34.30 \%$ & $24.19 \%$ & $17.46 \%$ \\
\hline dc14-dc15 & $81.06 \%$ & $52.90 \%$ & $34.76 \%$ & $24.54 \%$ & $18.45 \%$ \\
\hline de14-de16 & $78.68 \%$ & $61.69 \%$ & $46.90 \%$ & $37.37 \%$ & $31.71 \%$ \\
\hline de $15-d c 16$ & $76.21 \%$ & $50.19 \%$ & $29.93 \%$ & $19.37 \%$ & $13.43 \%$ \\
\hline
\end{tabular}

Pada kode dc1-dc2 dan dc11-dc12 adalah data abstrak yang sama tetapi memiliki perbedaan tahapan preprocessing, dc1-dc2 melewati semua tahapan preprocessing yaitu tahapan case folding, tokenizing, filtering, dan stemming, sedangkan kode dengan dc11dc12 hanya melewati tahapan case folding saja, begitu juga dengan semua kode contohnya cmp1-cmp2 dan cmp11- cmp12, cmp1cmp3 dan cmp11-cmp13 dan seterusnya. 
C. Pembahasan

Rata-rata dari setiap kata kunci dan total rata-ratanya sebagai berikut.

Tabel 20. Total rata-rata

\begin{tabular}{|c|c|c|c|c|c|c|}
\hline \multicolumn{2}{|l|}{ Kode } & 2 gram & 3 gram & 4 gram & 5 gram & 6 gram \\
\hline \multirow{3}{*}{ Android-Kripnografi } & Preprocessing & $93.57 \%$ & $88.43 \%$ & $84.36 \%$ & $81.66 \%$ & $79.10 \%$ \\
\hline & Case Folding & $93.93 \%$ & $89.46 \%$ & $84.37 \%$ & $80.93 \%$ & $78.50 \%$ \\
\hline & Total & $93.75 \%$ & $88.95 \%$ & $84.37 \%$ & $81.30 \%$ & $78.80 \%$ \\
\hline \multirow{3}{*}{ Mysql-Waterfall } & Preprocessing & $81.90 \%$ & $54.36 \%$ & $34.91 \%$ & $25.19 \%$ & $20.05 \%$ \\
\hline & Case Folding & $84.93 \%$ & $63.25 \%$ & $43.62 \%$ & $32.60 \%$ & $25.42 \%$ \\
\hline & Total & $83.42 \%$ & $58.80 \%$ & $39.26 \%$ & $28.90 \%$ & $22.73 \%$ \\
\hline \multirow{3}{*}{ Mysql-Visual Studio } & Preprocessing & $83.47 \%$ & $58.50 \%$ & $40.18 \%$ & $32.92 \%$ & $28.38 \%$ \\
\hline & Case Folding & $87.22 \%$ & $66.82 \%$ & $50.67 \%$ & $41.47 \%$ & $36.36 \%$ \\
\hline & Total & $85.35 \%$ & $62.66 \%$ & $45.43 \%$ & $37.19 \%$ & $32.37 \%$ \\
\hline \multirow{3}{*}{$\begin{array}{l}\text { Data Mining-Naïve } \\
\text { Bayes }\end{array}$} & Preprocessing & $78.19 \%$ & $51.05 \%$ & $36.99 \%$ & $29.02 \%$ & $23.64 \%$ \\
\hline & Case Folding & $81.11 \%$ & $59.14 \%$ & $43.83 \%$ & $34.64 \%$ & $28.78 \%$ \\
\hline & Total & $79.65 \%$ & $55.09 \%$ & $40.41 \%$ & $31.83 \%$ & $26.21 \%$ \\
\hline \multirow{3}{*}{$\begin{array}{l}\text { Waterfall-Sistem } \\
\text { Pendukung Keputusan }\end{array}$} & Preprocessing & $84.52 \%$ & $58.54 \%$ & $38.57 \%$ & $29.42 \%$ & $24.61 \%$ \\
\hline & Case Folding & $85.50 \%$ & $64.66 \%$ & $46.82 \%$ & $36.29 \%$ & $29.90 \%$ \\
\hline & Total & $85.01 \%$ & $61.60 \%$ & $42.69 \%$ & $32.85 \%$ & $27.26 \%$ \\
\hline \multirow{3}{*}{$\begin{array}{l}\text { Waterfall-Simple } \\
\text { Additive Weighting }\end{array}$} & Preprocessing & $93.84 \%$ & $85.68 \%$ & $78.88 \%$ & $74.71 \%$ & $71.43 \%$ \\
\hline & Case Folding & $95.05 \%$ & $90.55 \%$ & $85.94 \%$ & $83.48 \%$ & $81.52 \%$ \\
\hline & Total & $94.45 \%$ & $88.12 \%$ & $82.41 \%$ & $79.10 \%$ & $76.48 \%$ \\
\hline \multirow{3}{*}{$\begin{array}{l}\text { System Pendukung } \\
\text { Keputusan-Simple } \\
\text { Additive Weighting }\end{array}$} & Preprocessing & $85.16 \%$ & $58.40 \%$ & $38.58 \%$ & $30.02 \%$ & $25.42 \%$ \\
\hline & Case Folding & $86.14 \%$ & $65.14 \%$ & $47.36 \%$ & $37.33 \%$ & $31.24 \%$ \\
\hline & Total & $85.65 \%$ & $61.77 \%$ & $42.97 \%$ & $33.67 \%$ & $28.33 \%$ \\
\hline \multirow{3}{*}{$\begin{array}{l}\text { Customer Relationship } \\
\text { Management-Mysql- } \\
\text { Php }\end{array}$} & Preprocessing & $87.72 \%$ & $68.55 \%$ & $56.83 \%$ & $51.75 \%$ & $49.11 \%$ \\
\hline & Case Folding & $90.25 \%$ & $74.26 \%$ & $61.80 \%$ & $55.68 \%$ & $51.81 \%$ \\
\hline & Total & $88.99 \%$ & $71.41 \%$ & $59.31 \%$ & $53.72 \%$ & $50.46 \%$ \\
\hline \multirow{3}{*}{ Codeigniter-Php } & Preprocessing & $91.62 \%$ & $75.02 \%$ & $65.01 \%$ & $59.35 \%$ & $56.81 \%$ \\
\hline & Case Folding & $91.87 \%$ & $80.78 \%$ & $70.24 \%$ & $64.04 \%$ & $60.04 \%$ \\
\hline & Total & $91.75 \%$ & $77.90 \%$ & $67.63 \%$ & $61.70 \%$ & $58.43 \%$ \\
\hline \multirow{3}{*}{ Codeigniter-Mysql } & Preprocessing & $85.84 \%$ & $64.00 \%$ & $48.32 \%$ & $40.00 \%$ & $36.05 \%$ \\
\hline & Case Folding & $88.65 \%$ & $71.52 \%$ & $55.57 \%$ & $46.69 \%$ & $41.02 \%$ \\
\hline & Total & $87.24 \%$ & $67.76 \%$ & $51.95 \%$ & $43.35 \%$ & $38.54 \%$ \\
\hline \multirow{3}{*}{$\begin{array}{l}\text { Expert System } \\
\text { Development Life } \\
\text { Cycle-Sistem Pakar }\end{array}$} & Preprocessing & $85.46 \%$ & $60.51 \%$ & $42.49 \%$ & $34.30 \%$ & $30.13 \%$ \\
\hline & Case Folding & $87.53 \%$ & $66.47 \%$ & $49.56 \%$ & $39.02 \%$ & $34.48 \%$ \\
\hline & Total & $86.49 \%$ & $63.49 \%$ & $46.03 \%$ & $36.66 \%$ & $32.31 \%$ \\
\hline \multirow{3}{*}{$\begin{array}{l}\text { Augmented Reality- } \\
\text { Media Pembelajaran }\end{array}$} & Preprocessing & $86.78 \%$ & $82.30 \%$ & $76.79 \%$ & $72.87 \%$ & $69.90 \%$ \\
\hline & Case Folding & $89.36 \%$ & $86.17 \%$ & $82.04 \%$ & $78.35 \%$ & $74.89 \%$ \\
\hline & Total & $88.07 \%$ & $84.24 \%$ & $79.42 \%$ & $75.61 \%$ & $72.40 \%$ \\
\hline \multirow{3}{*}{ Data Mining-Padi } & Preprocessing & $85.40 \%$ & $73.68 \%$ & $61.85 \%$ & $54.72 \%$ & $50.45 \%$ \\
\hline & Case Folding & $88.56 \%$ & $79.24 \%$ & $67.67 \%$ & $60.49 \%$ & $55.66 \%$ \\
\hline & Total & $86.98 \%$ & $76.46 \%$ & $64.76 \%$ & $57.61 \%$ & $53.06 \%$ \\
\hline
\end{tabular}




\begin{tabular}{|c|c|c|c|c|c|c|}
\hline \multicolumn{2}{|l|}{ Kode } & 2 gram & 3 gram & 4 gram & 5 gram & 6 gram \\
\hline \multirow{3}{*}{ Data Mining-C45 } & Preprocessing & $76.11 \%$ & $48.05 \%$ & $31.70 \%$ & $24.40 \%$ & $20.00 \%$ \\
\hline & Case Folding & $78.85 \%$ & $55.81 \%$ & $38.86 \%$ & $29.67 \%$ & $24.00 \%$ \\
\hline & Total & $77.48 \%$ & $51.93 \%$ & $35.28 \%$ & $27.03 \%$ & $22.00 \%$ \\
\hline \multirow{3}{*}{$\begin{array}{l}\text { Manajemen Bandwith- } \\
\text { Wireless }\end{array}$} & Preprocessing & $88.15 \%$ & $78.49 \%$ & $72.91 \%$ & $69.78 \%$ & $67.71 \%$ \\
\hline & Case Folding & $89.25 \%$ & $79.85 \%$ & $74.52 \%$ & $70.23 \%$ & $68.15 \%$ \\
\hline & Total & $88.70 \%$ & $79.17 \%$ & $73.72 \%$ & $70.01 \%$ & $67.93 \%$ \\
\hline \multirow{3}{*}{ Web-Php } & Preprocessing & $89.79 \%$ & $66.77 \%$ & $49.45 \%$ & $40.84 \%$ & $36.26 \%$ \\
\hline & Case Folding & $90.36 \%$ & $73.54 \%$ & $56.87 \%$ & $47.15 \%$ & $40.80 \%$ \\
\hline & Total & $90.08 \%$ & $70.16 \%$ & $53.16 \%$ & $43.99 \%$ & $38.53 \%$ \\
\hline \multirow{3}{*}{ Web-Mysql } & Preprocessing & $86.64 \%$ & $62.59 \%$ & $44.16 \%$ & $34.89 \%$ & $30.22 \%$ \\
\hline & Case Folding & $88.65 \%$ & $69.87 \%$ & $51.90 \%$ & $41.77 \%$ & $35.26 \%$ \\
\hline & Total & $87.65 \%$ & $66.23 \%$ & $48.03 \%$ & $38.33 \%$ & $32.74 \%$ \\
\hline \multirow{3}{*}{ Codeigniter-Waterfall } & Preprocessing & $85.84 \%$ & $64.00 \%$ & $48.32 \%$ & $40.00 \%$ & $36.05 \%$ \\
\hline & Case Folding & $88.65 \%$ & $71.47 \%$ & $55.57 \%$ & $46.69 \%$ & $40.94 \%$ \\
\hline & Total & $87.24 \%$ & $67.74 \%$ & $51.95 \%$ & $43.35 \%$ & $38.49 \%$ \\
\hline \multirow{3}{*}{$\begin{array}{l}\text { Klasifikasi-Naïve } \\
\text { Bayes }\end{array}$} & Preprocessing & $81.74 \%$ & $65.01 \%$ & $54.46 \%$ & $48.19 \%$ & $44.34 \%$ \\
\hline & Case Folding & $82.27 \%$ & $71.48 \%$ & $58.46 \%$ & $50.52 \%$ & $45.02 \%$ \\
\hline & Total & $82.01 \%$ & $68.25 \%$ & $56.46 \%$ & $49.36 \%$ & $44.68 \%$ \\
\hline \multirow{3}{*}{ Total } & Preprocessing & $85.88 \%$ & $66.52 \%$ & $52.88 \%$ & $46.00 \%$ & $42.09 \%$ \\
\hline & Case Folding & $87.80 \%$ & $72.60 \%$ & $59.25 \%$ & $51.42 \%$ & $46.51 \%$ \\
\hline & Total & $86.84 \%$ & $69.56 \%$ & $56.06 \%$ & $48.71 \%$ & $44.30 \%$ \\
\hline
\end{tabular}

Dari data yang digunakan menghasilkan nilai rata-rata total kemiripan $86.84 \%$ pada 2 gram, $69.56 \%$ pada 3 gram, $56.06 \%$ pada 4 gram, $48.71 \%$ pada 5 gram, dan $44.30 \%$ pada 6 gram. Dimana nilai persentase kemiripan data mulai dari yang terkecil yaitu $70.55 \%$ pada 2 gram, $40.21 \%$ pada 3 gram, $20.71 \%$ pada 4 gram, $12.76 \%$ pada 5 gram, dan $8.25 \%$ pada 6 gram hingga yang tertinggi $100 \%$ pada semua $\mathrm{k}$ gram. Dari data yang digunakan dapat dilihat juga bahwa hasil dari Preprocessing (case folding, tokenizing, filtering, dan stemming) dengan hasil dari Preprocessing (case folding), memiliki perbedaan yaitu, hasil dari Preprocessing (case folding, tokenizing, filtering, dan stemming) lebih kecil persentase kemiripannya daripada hasil Preprocessing (case folding), hal ini disebabkan adanya penghilangan kata yang sering digunakan pada tahapan filtering dan adanya perubahan kata pada tahapan stemming.

\section{KESIMPULAN}

Pengujian dengan beberapa macam nilai k-gram (2 gram, 3 gram, 4 gram, 5 gram dan 6 gram) dan perbedaan pada preprocessing yaitu dengan menggunakan semua tahapan (case folding, tokenizing, filtering, dan stemming) dan hanya menggunakan tahapan case folding menghasilkan nilai kemiripan yang bermacam - macam, nilai rata-rata total kemiripannya yaitu $86.84 \%$ pada 2 gram, $69.56 \%$ pada 3 gram, $56.06 \%$ pada 4 gram, $48.71 \%$ pada 5 gram, dan $44.30 \%$ pada 6 gram. Hal ini dapat disimpulkan bahwa dari data yang digunakan masih terlihat adanya tindakan plagiarisme pada abstrak, hal ini didukung dengan adanya data yang memiliki nilai kemiripan hingga $100 \%$.

\section{PENGAKUAN}

Makalah ini adalah sebagian dari penelitian Tugas Akhir milik Indra Gunawan dan disponsori oleh Universitas Singaperbangsa Karawang.

\section{DAFTAR PUSTAKA}

[1] A. Millah and S. Nurazizah, "Perbandingan Penggunaan Algoritma Cosinus dan Wu Palmer untuk Mencari Kemiripan Kata dalam,” vol. 2, no. 1, p. 11, 2017.

[2] A. H. Purba and Z. Situmorang, “Analisis Perbandingan Algoritma Rabin-Karp Dan Levenshtein Distance Dalam Menghitung Kemiripan Teks,” vol. 02, p. 9, 2017.

[3] L. Sibarani, M. Magdalena, and A. Dharma, "Analisa Perbandingan Sistem Pendeteksian Kemiripan Judul Skripsi Menggunakan Algoritma Winnowing Dan Algoritma Rabin Karp,” remik, vol. 4, no. 1, p. 69, Oct. 2019, doi: 10.33395/remik.v4i1.10174.

[4] T. Suryati, Y. Wibisono, and Y. Wihardi, “Aplikasi Deteksi Plagiarisme Dokumen Skripsi dengan Algoritma Rabin-Karp,” vol. 1, no. 2 , p. 5, 2018.

[5] R. Satria, "IDENTIFIKASI BENTUK TINDAK PLAGIAT PADA PENULISAN SKRIPSI MAHASISWA PROGRAM STUDI PENDIDIKAN FISIKA UNSYIAH," p. 7. 
[6] A. Filcha and M. Hayaty, "Implementasi Algoritma Rabin-Karp untuk Pendeteksi Plagiarisme pada Dokumen Tugas Mahasiswa,” Juita, vol. 7, no. 1, p. 25, May 2019, doi: 10.30595/juita.v7i1.4063.

[7] A. Sukmana and A. Sunyoto, "PERBANDINGAN PENGUNAAN STEMMING PADA DETEKSI KEMIRIPAN DOKUMEN MENGGUNAKAN METODE RABIN KARP DAN JACCARD SIMILARITY,” p. 6, 2018.

[8] D. Steveson, H. Agung, and F. Mulia, "APLIKASI PENDETEKSI PLAGIARISME TUGAS DAN MAKALAH PADA SEKOLAH MENGGUNAKAN ALGORITMA RABIN KARP,” J-ALU, vol. 1, no. 1, May 2018, doi: 10.30813/j-alu.v1i1.1104.G. Eason, B. Noble, and I. N. Sneddon, “On certain integrals of Lipschitz-Hankel type involving products of Bessel functions,” Phil. Trans. Roy. Soc. London, vol. A247, pp. 529-551, April 1955. (references) 